\section{The Functions of the Nervus Intermedius}

We read with extreme interest the article written by Burmeister et al entitled "Identification of the Nervus Intermedius Using 3T MR Imaging." It is surprising that this minute nerve has gained such a wide clinical, functional, and now radiologic interest since the original description in 1778 by Wrisberg. ${ }^{2}$

However, there is a point of concern in the article. The authors stated in the introduction that one of the functions of the nervus intermedius (NI) is the "sensory and parasympathetic innervation of the parotid gland." This sentence is somewhat troubling, and we cannot agree with it.

To our knowledge, the NI innervates the lacrimal, submandibular, and sublingual glands. The afferent component of the NI carries sensorial perception from the skin of the external auditory meatus and from the nasopharynx and nose; and taste from the anterior twothirds of the tongue, floor of the mouth, and the palate. ${ }^{3}$ Moreover, contemporary intraoperative electrophysiologic observations have shown an unforeseen electromyographic activity of perioral muscles after NI stimulus, ${ }^{4,5}$ which can help in the operative recognition of the nerve and may involve the presence of a small amount of motor fibers.

On the other hand, it is generally accepted that the parasympathetic innervation of the parotid gland originates in the inferior salivary nucleus, leaving the brain stem through the tympanic nerve, a branch of the ninth cranial nerve. From then on, the fibers convey into the lesser petrosal nerve entering the otic ganglion. The parotid gland is, thereafter, reached through the auriculotemporal nerve, a subdivision of the mandibular subdivision of the trigeminal nerve. ${ }^{6}$

In conclusion, we could not find any suggestion that the NI innervates the parotid gland directly.

\section{References}

1. Burmeister HP, Baltzer PA, Dietzel M, et al. Identification of the nervus intermedius using 3T MR imaging. AJNR Am J Neuroradiol 2011;32:460-64. Epub 2011 Feb 3

2. Alfieri A, Strauss C, Prell J, et al. History of the nervus intermedius of Wrisberg. Ann Anat 2010;192:139-44

3. Gacek R, Lyon MJ. Evidence of a gustatory-vestibular pathway for protein transport. Otol Neurotol 2010;31:313-18

4. Scheller C, Rachinger J, Prell J, et al. Schwannoma of the intermediate nerve. J Neurosurg 2008;109:144-48

5. Ashram YA, Jackler RK, Pitts LH, et al. Intraoperative electrophysiologic identification of the nervus intermedius. Otol Neurotol 2005;26:274-79

6. May M, Shaitkin B. The Facial Nerve. New York: Thieme Medical Publisher; 2000

A. Alfieri

J. Fleischhammer

J. Prell

Martin Luther University

DOI 10.3174/ajnr.A2624 